\title{
Hidden from our sight, but not from our impact: the conservation issues of cave bivalves
}

\author{
Helena Bilandžija ${ }^{1}$, Sanja Puljas², Marco Gerdol ${ }^{3 *}$ \\ ${ }^{1}$ Department of Molecular Biology, Rudjer Boskovic Institute, Bijenicka 54, 10000 Zagreb, Croatia \\ ${ }^{2}$ Department of Biology, Faculty of Science, University of Split, Ruđera Boškovića 33, Split, Croatia \\ ${ }^{3}$ Department of Life Sciences, University of Trieste, Via Giorgieri 5, 34127 Trieste, Italy \\ *correspondence should be addressed to mgerdol@units.it
}

\begin{abstract}
Groundwater habitats in the Dinaric Karst are home to the only known cave-adapted genus of bivalve mollusks, which currently survives as three distinct species with a highly fragmented distribution. Over the past few decades, Congeria populations suffered a steep decline across their range, as a result of human activities. Here, we identify the most pressing issues concerning the current conservation status of Congeria and identify key priorities for its scientific study. The building of dams and other hydrotechnical constructions have led to a significant decrease in the water inputs that used to supply underground systems where Congeria lives, contributing to a reduction of the cave habitats feasible for bivalve settlement. This is relatively well documented in Popovo polje where, as a result of hydrotechnical interventions on Trebisnjica river, water level drop destroyed well over $99 \%$ of Congeria kusceri population in Zira cave and caused their complete disappearance in other caves. Similar factors are likely to have also affected the sister species Congeria jalzici in the Lika region. In addition, the salinization of Neretva river, lack of proper wastewater management, intense agriculture, tourist exploitation, and additional hydrotechnical plans add to the ongoing decline of the quality of Congeria habitats. These threats are expected to least to drastic reductions in population size within the next few decades, and this situation might be further aggravated by the lack of regulations and active measures for Congeria protection, as well by the limited understanding of its biology. Future scientific studies should be aimed at better elucidating microhabitat preference, defining the range of tolerance of environmental parameters, and assessing the size and genetic viability of existing Congeria populations. However, we highlight that these efforts would most certainly require the collaboration of local authorities and the allocation of appropriate financial resources in order to be effective.
\end{abstract}

\section{Keywords}

bivalvia, cave adapted, conservation efforts, Dreissenidae, endangered, filter feeding, habitat destruction, human impact, stygofauna

\section{Evolutionary origins and unique features of the only known extant genus of cave-dwelling bivalves}

The Dinaric Karst in Croatia, Slovenia and Bosnia and Herzegovina, is one of the most valuable hotspots of subterranean biodiversity in the world, believed to be the results of past intense geological events that drove speciation and migration (Culver \& Sket, 2000). Due to their isolation, subterranean environments are typically associated with reduced seasonal variation in abiotic conditions, such as temperature, humidity, and water 
chemistry, compared to epigean environments. Additionally, scarce food availability makes hypogean systems energy-limited compared to photosynthesis-based epigean systems (Hüppop, 2012). To cope with these unique conditions, cave animals have evolved numerous morphological and physiological adaptations, and they have adopted life history traits associated with K-selection, such as delayed reproduction, low fecundity, larger eggs, and increased longevity compared to their epigean relatives. According to Culver (1982), nearly all cave organisms exhibit either some or all of the above traits.

While over 350 gastropod mollusks have been described in subterranean environments (Culver, 2012), only a single genus of cave-dwelling bivalves is currently known. In addition to its unique habitat, the peculiarity of the genus Congeria also lies in its being a tertiary relict and a species endemic to Dinaric Karst. During the Tertiary Period, members of the family Dreissenidae Gray, 1840 were widespread in the Paratethys Sea. The sister genera Mytilopsis and Congeria diverged from Dreissena 37.4 MYA in the late Eocene and Congeria diverged from Mytilopsis in the early Miocene (i.e. 22.8 MYA) (Bilandžija et al., 2013). Following the turbulent evolution and the occurrence of major radiations of Dreissenidae in Paratethyan basins, most species of Congeria became extinct at the end of Miocene. Only a single lineage survived by adapting to the subterranean environment (Morton, Velkovrh \& Sket, 1998; Stepien et al., 2001; Bilandžija et al., 2013; Morton \& Puljas, 2013). Even though Congeria has long been thought to survive as a single pan-dinaric species, phylogenetic analyses have recently clarified that it consists of three distinct relict species, namely Congeria kusceri Bole, 1962, Congeria mulaomerovici Morton \& Bilandžija, 2013, and Congeria jalzici Morton \& Bilandžija, 2013. These are the products of speciation events estimated to have occurred in the Pliocene (Bilandžija et al., 2013).

Among the unique life history traits that characterize cave adapted animals, Congeria species exhibit K-selection and larval brooding as well as a very long lifespan compared to most other bivalves, which rarely survive longer than 15 years in the wild (Moss et al., 2016). In fact, a survey carried out in the Jama u Predolcu cave revealed the presence of individuals of $C$. kusceri older than 50 years of age (Puljas et al., 2014). Moreover, this species reaches sexual maturity at the age of 10 years, has an annual reproductive cycle and produces just a few offspring, which are initially bred in maternal ctenidia and later live as juveniles in mantle pouches (Morton \& Puljas, 2013). These characteristics of Congeria stand in stark contrast to its opportunistic, $r$-selected, epigean cousins Dreissena and Mytilopsis (Puljas et al., 2014).

Due to their association with a very stable habitat, subterranean species are not expected to tolerate large fluctuations in environmental parameters. However, Congeria species seem to be well adapted to the variable water regimes typical of karst due to their long-term adaptive history, to the point that water level plays an important role in controlling their life cycle (Morton \& Puljas, 2013; Puljas et al., 2014; Jovanović Glavaš, Jalžić \& Bilandžija, 2016; OIKON \& Elektroprojekt, 2016). Specifically, the annual reproductive cycle and shell growth pattern of Congeria require periods of higher water levels and lower water temperatures during winter, alternating with periods of lower water levels and higher water temperatures during summer. Temperature rise appears to be the primary regulator of shell growth, but it is also the primary trigger that coordinates reproductive timing and larval brooding (Morton and Puljas, 2013). Therefore, all extant species of the genus Congeria show notable tolerance to temperature fluctuations and air exposure (Morton \& Puljas, 2013; Puljas et al., 2014; Jovanović Glavaš, Jalžić \& Bilandžija, 2016; OIKON \& Elektroprojekt, 2016).

Congeria kusceri is currently listed as a vulnerable (VU) species in the European Red List of non-marine mollusks (Cuttelod, Seddon \& Neubert, 2011) and as a critically endangered (CR) species in the Croatian red list of subterranean fauna (Bilandžija \& Jalžić, 2009). It is also listed in the Annex II of the EU Habitats Directive. Defining potential threats posed by human activities to all Congeria species would be the first step in effectively managing their conservation. With this respect, specific hydrological conditions are necessary for normal functioning of life cycle in Congeria. Due to severe range restriction, even a single local event can have a major impact on a number of different populations. Alterations of water levels in the karst underground, especially when associated with 
pollution, could negatively affect reproduction and disrupt the gametogenic cycle, the regulation of the onset and end of the spawning season, and the dispersal of developing larvae. This may lead to severe long-term population declines in a species whose resilience and recovery potential is likely very limited due to low reproductive rates, slow growth and maturation as well as low dispersal potential. A recent study (Chichorro et al., 2020) identified the traits that are more strongly correlated with extinction risks across the tree of life. Unfortunately, all of these, i.e. narrow habitat breadth, poor dispersal ability, low fecundity, small altitudinal range, and the presence of a large human footprint, are shared by Congeria species, which should therefore be considered as highly susceptible to extinction.

\section{Extrinsic threats and the impact on Congeria populations in the Neretva and Lika river basins}

Congeria kusceri inhabits subterranean parts of the Neretva river basin in southern Herzegovina and Dalmatia. Today, living populations are known from 8 sites, 3 on the northwestern and 5 on the southeastern side of the river (Bilandžija et al., 2013). The upper part of the Neretva River and many of its tributaries have been heavily impacted by hydrotechnical constructions (Figure 1), with significant consequences on subsurface water levels. Perhaps the most drastic and well-documented change occurred in the Trebišnjica River, a tributary of Neretva. Under natural hydrological regimes, the river used to be sinking in the western part of Popovo polje, leading every year to the flooding of the lower parts of the polje from October to June. The building of an accumulation reservoir and the canalization of the river in a concrete channel (Figure 2A), which occurred during the sixties, currently prevent the release of the biological minimum to supply the underground conduits connecting Trebišnjica and Neretva. As a result, nearly 500 sinkholes and caves in Popovo polje lost their annual water supply and now rely only on precipitation, and many springs on the right bank of Neretva and along the Adriatic coast in this area have dried up (Vranješ, Prskalo \& Džeba, 2013). According to the personal report of Mr. Markica Vuica, owner of the property above the Jama u Predolcu cave, located on the right bank of the lower Neretva, the water level in the cave is now 10 meters lower than it used to be when he was a child.

The impact of these human activities on $C$. kusceri can only be estimated indirectly, as no surveys were carried out prior to the construction work to determine the status of the populations and their vulnerability. In his work, Bole (1962) listed three locations where living populations used to occur in Popovo polje: the caves Žira, Meginja and Baba (kod Strujići), with the population in Meginja being particularly abundant. Sixty years after this report, mussels currently only survive in Žira ponor, whereas the populations originally found in Meginja and Baba have completely disappeared. Žira ponor, the westernmost site in Popovo polje, is the type locality of $C$. kusceri (Figure $2 \mathrm{~B}, \mathrm{C}$ ). The bottom of the cave is about $20 \mathrm{~m}$ below the level of the polje, which means that before hydrotechnical constructions most of the cave used to be flooded all year round or at least between October and June. Nowadays only a small and shallow lake, which dries up almost completely during the summer months, remains in the last chamber of the cave. Bole (1962) described that Congeria bivalves used to cover all the walls in the lowest section of Žira Cave in $10 \mathrm{~cm}$ thick layers. Today, mussel clutches are only found in a small area of the wall, measuring about $6 \mathrm{~m}^{2}$, and the entire floor is filled with empty shell debris (Figure 2D). To illustrate the detrimental impact of human activities on the population size of Congeria, we focus here only on the lowest area of the last chamber. The diameter of the area is about $15 \mathrm{~m}$, and its height in the lowest part is 4 meters. If we ignore the surface of the ceiling, as well as the fact that the walls are irregular and full of bumps, cracks and crevices, we can estimate that an area of $188 \mathrm{~m}^{2}$ is potentially available for the settlement of mussels. Therefore, a very conservative estimate suggests that the surviving Congeria population in Žira ponor might have decreased by more than $99 \%$ following changes that affected the flow of Trebisnjica River. If we add that mussels used to form $10 \mathrm{~cm}$ thick layers and that they also lived in other parts of the cave, the reduction of the population may 
possibly be several fold higher. The same estimates, which represent one of the most striking and welldocumented examples of the decline of a cave-dwelling species, might also apply to other caves in Popovo polje. The disappearance of populations of $C$. kusceri has been documented at another site: the spring cave Izvor-špilja kod kapelice Sv. Mihovila. Since live mussels were found after major hydrotechnical interventions had already been completed in the area (Jalžić, 1998), we can presume that other factors caused their disappearance. One possible reason is widening of the cave entrance, which led to an increase of the amount of light that nowadays reaches the end of this small spring. Although direct light exposure is unlikely to have such a detrimental effect, as $C$. kusceri can survive under laboratory conditions for months, cave bivalves are albino and it is unknown whether long-term sun exposure might cause cellular damage and whether it is reparable. Moreover, increased light exposure might have significantly modified the ecosystem of the spring, causing for example an alteration of the composition of microbial communities. According to a recent study, $C$. kusceri is associated with chemolithoautotrophic bacteria (Rigonni et al., 2021 in print) and is likely therefore to be very sensitive to the quality and quantity of microbial communities. This example highlights how seemingly insignificant changes, such as widening of the cave entrance by half a meter, can lead to the disappearance of entire Congeria populations. Another significant issue for the conservation of the species is the deterioration of water quality in the Neretva River basin due to the high inputs of fertilizers, pesticides and other pollutants linked with the inadequate wastewater management system and the intensive agriculture in the area (Figure 2E,F). Even worse, seawater infiltrates the lower Neretva and increases salinity. This phenomenon is particularly strong during the dry summer months due to the lack of flow, as most of the water is trapped in a series of dams upstream (Vranješ, Prskalo \& Džeba, 2013). Further hydrotechnical construction works are underway in the upper parts of the basin as part of the "Gornji Horizonti" project. Water from the Neretva basin will be diverted to the Trebisnjica basin for power generation. This will undoubtedly cause a further increase in salinity and deterioration of water quality in the delta region.

Finally, construction works, which included widening of the entrance and building of a platform, have been recently undertaken in the Jama u Predolcu cave to facilitate tourist visits. Hopefully, these works will not cause severe damage to $C$ kusceri population in the cave but we may not be able to know that because Croatian authorities have issued permits without a previous assessment of the impact of tourist activities on the fauna or a determination of its current status and monitoring possibilities. In recent years, large amounts of sediment have occasionally appeared in the cave lakes, likely as a result of the pumping of water through a nearby tunnel that may be connected to the cave. This led to the deposition of small particles on walls of the cave and on all the filter feeding organisms that live on the surface, i.e. the mussel Congeria, the polychaete tubeworm Marifuga cavatica and the sponge Ephydatia fluviatilis. Filter feeders are only very rarely found in the subterranean environment, and only four caves in the world, all located in the Dinaric Karst, are known to harbor a community of filter feeders as complex as the one found in Jama u Predolcu. As mentioned above, chemolithoautotrophic production, as discovered in the nearby cave Pukotina u tunelu polje Jezero - Peračko Blato, can support this system. Therefore, $C$. kusceri is part of a unique and fragile subterranean ecosystem, which is threatened by growing, but still poorly documented, impact of human activities.

Even though Congeria jalzici lives in the sparsely populated Lika region (Bilandžija et al., 2013), hydrotechnical engineering represents a serious threat to its populations. Indeed, the Lika River is dammed, and its water flow stops before reaching the sinkholes at the end of Lipovo polje, where Congeria sites are located. Since no research was conducted in the caves before the construction of the dam and Congeria was discovered decades later (Jalžić, 2001), the impact of this construction is unknown and can only be extrapolated from the situation with C. kusceri in Popovo polje, which is similar because all caves in both Popovo and Lipovo polje are cut off from their water supply. The layer of empty shells debris found in Markov ponor, the type locality of $C$. jalzici, is up to $1 \mathrm{~m}$ thick in some areas of the cave, which is even more than in Žira ponor. Currently, the greatest known 
threat to any surviving Congeria population lies in another large hydrotechnical construction project and in the construction of a new dam in this region. While, unlike in the past, studies are currently being carried out to assess the impact of these activities, their funding and control by the investor poses serious ethical questions about the reliability of the results of such investigations, as they may be influenced by the financial relationships that exist between the investor and companies employed for the assessment.

Global climate change is generally considered as a significant threat to subterranean communities (Mammola et al., 2019a, 2019b). As noted above, Congeria can survive a range of temperatures, but it is not known in what way temperature changes, along with the consequent alteration of abiotic or biotic components of the ecosystem, will affect populations in the long term. A potential change in precipitation dynamics caused by climate change may lead to a decrease in cave humidity as well as an increase in the time period that mussels have to survive out of water, which is currently about 2 months (Jovanović Glavaš, Jalžić \& Bilandžija, 2016). Because subterranean communities live in an environment with low variability, many cave animals are not expected to have high tolerance (Mammola et al., 2019b), and some components of the biotic community may face future extinction due to an increase in temperature. Due to our limited knowledge of cave food webs, the interspecific relationships of Congeria are largely unknown and therefore the impact of their alteration cannot be reliably predicted (Rigonni, Bilandžija \& Engel, 2021). Our poor knowledge of many aspects of Congeria ecology, such as its critical survival requirements, is exemplified by our inability to explain the patchy distribution of these bivalves within localities. For example, $C$. jalzici lives in a few small areas within the more than $1.5 \mathrm{~km}$ long Markov Ponor cave, where microhabitats are certainly highly heterogeneous. However, it is unclear why mussels choose certain areas of the cave and not others for their settlement.

\section{Future directions for improved conservation efforts}

The need for increased genetic studies has been previously identified as a priority for the conservation of endangered freshwater mussels, both to preserve existing genetic diversity in current populations and to minimize the risk of genetic hazards in case of restoration programs (Jones, Hallerman \& Neves, 2006; LopesLima et al., 2014). Nevertheless, such studies are still in their infancy and are mostly limited to estimating intraspecific genetic diversity within and between populations using several molecular markers (Curole, Foltz \& Brown, 2004; Grobler et al., 2006; Chong, Harris \& Roe, 2016). On the other hand, the inherent complexity and relatively large size of bivalve genomes have long hindered the application of whole-genome scale approaches in these organisms. However, the development of third-generation sequencing technologies and the possibility of using proximity ligation library preparation methods have recently facilitated the extension of genomic studies to bivalves (Zhang et al., 2012; Calcino et al., 2019; Gerdol et al., 2020).

Currently available genetic resources for Congeria spp. are limited to a few molecular markers (i.e., COI, CytB, $16 \mathrm{~S}, 18 \mathrm{~S}$, and $28 \mathrm{~S}$ rRNA) generated during phylogeographic studies that helped establish the presence of three distinct species in the Dinaric Karst area (Bilandžija et al., 2013). Although cytogenetic estimates of the nuclear DNA content of Congeria are not available, the genome size is expected to be similar to the phylogenetically related dreissenids D. rostriformis and D. polymorpha, i.e., 1.6 Gb (Calcino et al., 2019; McCartney et al., 2019), which would make Congeria a feasible target for whole-genome sequencing approaches.

Given the rapid decline or disappearance of Congeria populations observed in recent decades, the availability of this resource would provide an important tool for understanding the mechanisms of adaptation of this species to the subterranean environment, as has been previously done for other cave-dwelling species (McGaugh et al., 2014). Genome assembly along with the creation of a comprehensive atlas of expressed transcripts in various tissues would allow for better targeting of future conservation efforts. These goals would be consistent with those of major large-scale initiatives recently launched (such as European Reference Genome Atlas - ERGA and 
the Earth BioGenome Project) that aim to obtain high-quality, near-complete, and error-free chromosome-level genome assemblies of endemic threatened species to protect and restore biodiversity (Kiel et al., 2020).

At the same time, this would be an invaluable resource for studying existing intraspecific variation across different sites where living populations have been reported to date. Indeed, understanding the genetic structure of a species, estimating effective population size, and detecting gene flow among populations in species with fragmented distributions are essential prerequisites for identifying conservation units (Moritz, 1994). In particular, identifying sites characterized by high genetic diversity or the presence of unique haplotypes would be a priority for improving conservation strategies, as has been suggested for other endangered freshwater bivalves (Elderkin et al., 2007).

Previous studies have suggested that Congeria populations maintain relatively high levels of intraspecific genetic diversity, unlike many endangered epigean freshwater mussels (Skidmore et al., 2010). This could be the result of the long-term maintenance of population size driven by relatively constant conditions of the subterranean environment over the last few hundred thousand years (Stepien et al., 2001). Nonetheless, the application of approaches such as RADseq/2b- RAD could help improve our knowledge of the factors associated with high fragmentation of the current range and the lack of connectivity among populations. For example, persistent inbreeding and genetic bottlenecks may affect some isolated populations and pose a threat to their long-term genetic viability. Gathering these information could also be useful for planning potential future reintroduction efforts, with particular attention to the presence of genetic differentiation among populations (Grobler et al., 2006), following the example of ongoing projects for endangered freshwater mussels in Northern America (Garrison, Johnson \& Whelan, 2020).

Another potential application of modern genetic approaches to the conservation of Congeria lies in the use of environmental DNA (eDNA) as a proxy to define the exact range of the species. This approach would help determining whether living populations are extinct or still present at sites where living specimens have been documented in historic times as well as allow investigating the presence of unreported populations in springs and subterranean conduits which are not accessible to humans. This could, for example, shed light on the still unresolved close genetic relationship between $C$. jalzici populations found in the regions of Bela Krajina (Slovenia) and Lika (Croatia), which are separated by a distance of about $100 \mathrm{~km}$ and belong to different river basins (Bilandžija et al., 2013).

Useful decisions on conservation measures needed to preserve Congeria species rely on expediting research in all areas of the biology and ecology of the species. Current important unsolved issues include the clarification of the relationships between different components of subterranean communities, the resilience of these communities towards changing environmental conditions, the basis and plasticity of their unique adaptations, and the range of abiotic conditions that is suitable for the long-term preservation of living populations. The high rate of new species discovered every years in caves around the world indicates that subterranean biodiversity is still largely unexplored, especially meio- and microbiotic components of the system. The functional roles covered by individual species within the community and their inter- and intraspecific interactions are even more mysterious. For example, the main food sources used by Congeria and by other filter feeders found in the same community are presently unknown. The identity of chemoautotrophic primary producers in Congeria caves, the biotic and abiotic factors that drive their persistence through space and time and the extent by which the whole subterranean system relies on chemoautotrophy vs allochthonous inputs remain open questions to be urgently answered in order to decipher the structure of food webs in these caves. Gathering a mechanistic understanding of the adaptations that allowed Congeria to survive the extinction events that wiped out all other dreissenids at the end of Pliocene and to colonize caves would be equally important. This would allow to improve our understanding of the evolutionary history of Congeria, to test the extent of plasticity of these adaptive traits and to predict the limits of adaptability and resilience of the species to a range of abiotic conditions which may be 
encountered in their habitats. Another pressing task is the development of methods to produce reliable estimates of population sizes and trends. So far, the only population size estimate was done in Jama u Predolcu, a relatively small cave, and this required the work of 4 cave divers over 10 days (Jovanović Glavaš, Jalžić \& Bilandžija, 2016). The inherent problems linked with underwater investigation in caves and the significant funding that would be required to carry out similar estimates in other locations or even routine monitoring makes it unlikely that similar endeavors will be undertaken in the near future. Although a series of alternative methods has been proposed (Bilandžija, Puljas \& Čuković, 2014) they still need to be tested, improved and validated.

\section{Concluding remarks}

Numerous studies are concordant in affirming that the growing impact of human activities on Earth's biota is leading to a sixth "mass extinction" period, with a rate of species loss possibly up to 100 times higher than the background extinction rate (Ceballos et al., 2015). Aquatic species living in highly stable subterranean environments and associated to fragile ecosystems are most definitely among the most vulnerable species. Sixty years after its formal scientific description, Congeria, the only known extant genus of cave-dwelling bivalves, is already facing a serious threat of extinction. Altogether, its fragmented geographical distribution, the increasing impact of human activities on underground water regimes, the declining quality of its habitats and the lack of appropriate regulations for its protection highlight the need to rush into a race against time to better comprehend the basic ecological and physiological aspects of these unique species. Only an in-depth understanding of the resilience potential of the species, as well as of the current status of survival populations, together with the intervention by local authorities and with the allocation of adequate financial resources for its conservation would allow to act, before it is too late. 


\section{Figures and figure legends}

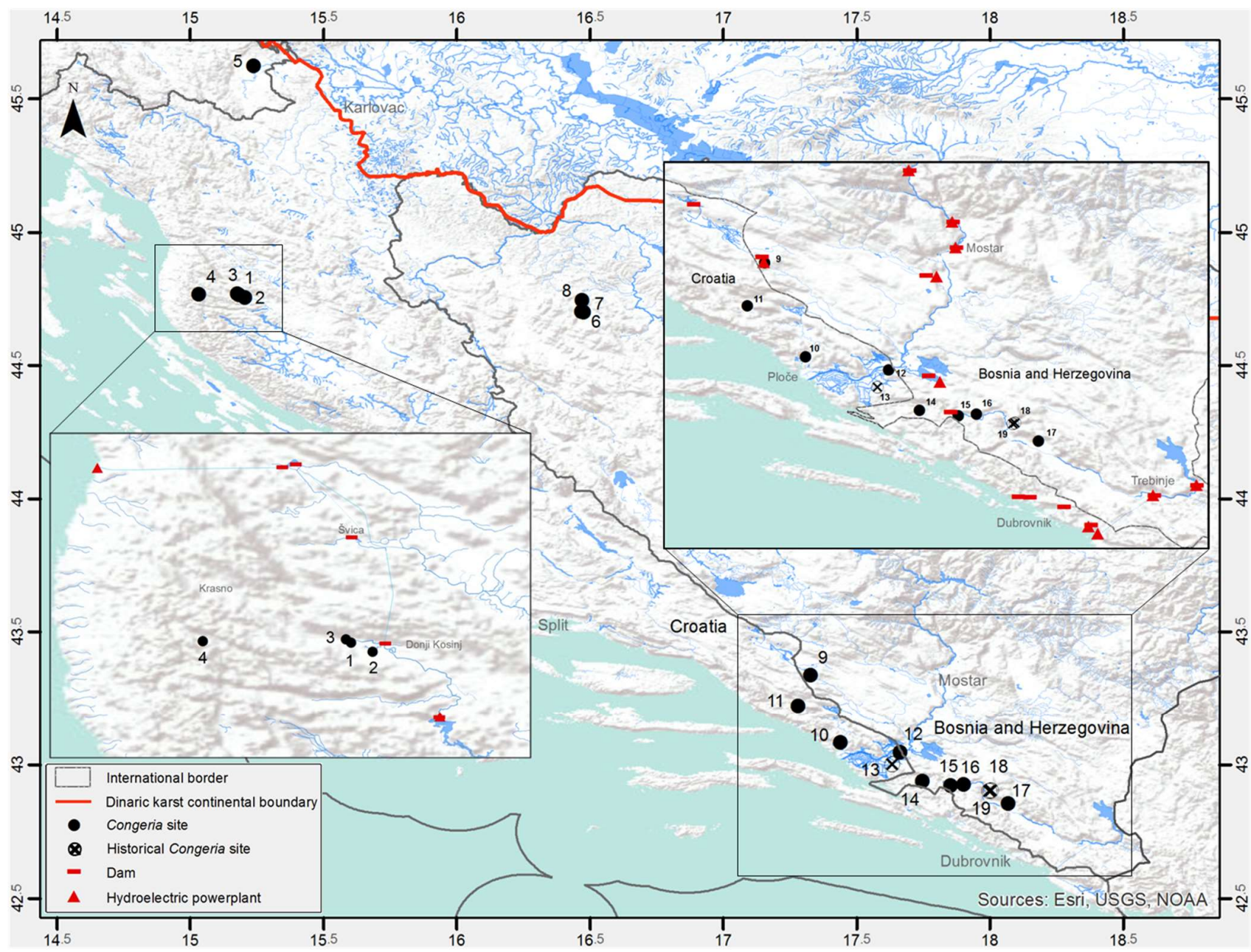

Figure 1. Map of localities of all three species of Congeria and hydrotechnical construction in Neretva and Lika river basins. 1. Markov ponor, 2. Dankov ponor, 3. Drazica ponor, 4. Lukina jama, 5. Izvir jamske skoljke, 6. Suvaja pecina, 7. Oko, 8. Dabarska pecina, 9. Tihaljina izvor, 10. Pukotina u tunelu polje Jezero - Peracko Blato, 11. Jasena ponor, 12. Jama u Predolcu, 13. Izvor-spilja kod kapelice Sv. Mihovila, 14. Gradnica, 15. Zira pecina, 16. Doljasnica ponor, 17. Plitica, 18. Baba pecina, 19. Meginja jama. 

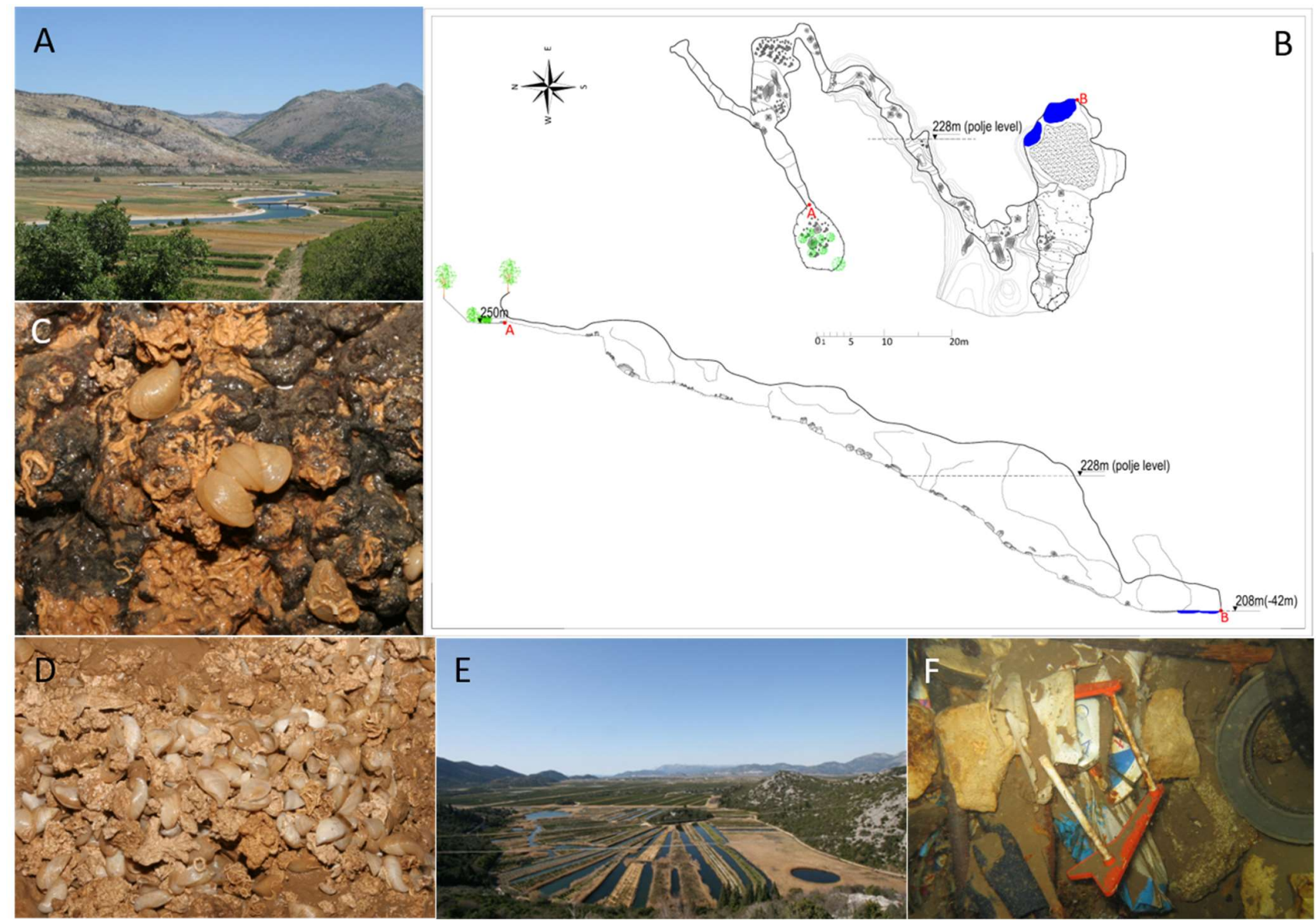

Figure 2. Anthropogenic threats in the distribution area of Congeria kusceri. 2A. River Trebišnjica in Popovo polje is entirely canalized and no biological minimum is released to supply subterranean conduits leading to significant lowering of the water table. 2B. The topographic map of Žira cave, the type locality of $C$. kusceri. The cave used to be flooded at least 9 months each year and at least to the level of polje, but after hydrotechnical construction of Trebišnjica river, it relies only on precipitation for water input and is mostly dry. Cave surveyed by Domagoj Tomašković and Helena Bilandžija, CBSS, SKS. Map drawn and edited by Domagoj Tomašković. 2C A group of Congeria kusceri bivalves from Žira cave. We estimate that as little as $0,1 \%$ of historical population survived to this day. 2D. Congeria shell debris in the bottom of Žira ponor cave. 2E. Lower Neretva river is the region of intense agricultural activities. 2F. Waste at the bottom of Jama u Predolcu cave in Metković, a site with unique subterranean community. Photos by Helena Bilandžija (2C,D,E) and Branko Jalžić (2A,F). 


\section{Acknowledgements}

We would like to dedicate this paper to our dear friend, mentor and colleague, late prof. Brian Morton. We wish to thank dr.sc. Tatjana Vujnović for her help in drawing the map of Congeria localities (Figure 1), Domagoj Tomašković for his help in drawing and editing the topographic map of Žira ponor cave (Figure 2A), Branko Jalžić, Vedran Sudar and Damir Basara for their help with the literature and Branko Jalžić and Zoran Drmac for allowing the use of their photographs. HB is funded by the Tenure Track Pilot Programme of the Croatian Science Foundation and the Ecole Polytechnique Fédérale de Lausanne within the Project TTP-2018-07-9675 EvoDark with funds of the Croatian-Swiss Research Programme. MG is supported by the University of Trieste Microgrants 2020 funding program.

\section{References}

Bilandžija, H. \& Jalžić, B. (2009). Dinaric cave clam, Congeria kusceri Bole. Red Book of Croatian Cave Dwelling Fauna. Ozimec R, Zagreb KL: Croatia, pp. 67-68.

Bilandžija, H., Morton, B., Podnar, M. \& Ćetković, H. (2013). Evolutionary history of relict Congeria (Bivalvia: Dreissenidae): unearthing the subterranean biodiversity of the Dinaric Karst. Frontiers in Zoology, 10(1), 5. https://doi.org/10.1186/1742-9994-10-5

Bilandžija, H., Puljas, S. \& Čuković, T. (2014). Monitoring protocol for Congeria kusceri Bole, 1962 and Congeria jalzici Morton \& Bilandžija, 2013 in Croatia. Croatian biospeleological society, 48.

Bole, J. (1962). Congeria kuščeri sp. n. (Bivalvia, Dreissenidae). Biološki Vestnik, (10), 55-61.

Calcino, A.D., de Oliveira, A.L., Simakov, O., Schwaha, T., Zieger, E., Wollesen, T., et al. (2019). The quagga mussel genome and the evolution of freshwater tolerance. DNA Research, 26(5), 411-422. https://doi.org/10.1093/dnares/dsz019

Ceballos, G., Ehrlich, P.R., Barnosky, A.D., García, A., Pringle, R.M. \& Palmer, T.M. (2015). Accelerated modern human-induced species losses: Entering the sixth mass extinction. Science Advances, 1(5), e1400253. https://doi.org/10.1126/sciadv.1400253

Chichorro, F., Urbano, F., Teixeira, D., Väre, H., Pinto, T., Brummitt, N., et al. (2020). Species traits predict extinction risk across the Tree of Life. bioRxiv, 2020.07.01.183053. https://doi.org/10.1101/2020.07.01.183053

Chong, J.P., Harris, J.L. \& Roe, K.J. (2016). Incongruence between mtDNA and nuclear data in the freshwater mussel genus Cyprogenia (Bivalvia: Unionidae) and its impact on species delineation. Ecology and Evolution, 6(8), 2439-2452. https://doi.org/10.1002/ece3.2071

Culver, D. (2012). Mollusks. Encyclopedia of caves. White WB, Culver DC: Amsterdam, The Netherlands.

Culver, D. \& Sket, B. (2000). Hotspots of subterranean biodiversity in caves and wells. Journal of Caves and Karst Studies, 62(1), 11-17.

Culver, D.C. (1982). Cave Life - Evolution and Ecology. Harvard University Press: Cambridge, Massachusetts.

Curole, J.P., Foltz, D.W. \& Brown, K.M. (2004). Extensive allozyme monomorphism in a threatened species of freshwater mussel, Margaritifera hembeli Conrad (Bivalvia: Margaritiferidae). Conservation Genetics, 5(2), 271-278. https://doi.org/10.1023/B:COGE.0000030005.14751.76

Cuttelod, A., Seddon, M. \& Neubert, E. (2011). European Red List of Non-marine Molluscs. European Union.

Elderkin, C.L., Christian, A.D., Vaughn, C.C., Metcalfe-Smith, J.L. \& Berg, D.J. (2007). Population genetics of the freshwater mussel, Amblema plicata (Say 1817) (Bivalvia: Unionidae): Evidence of high dispersal and 
post-glacial colonization. Conservation Genetics, 8(2), 355-372. https://doi.org/10.1007/s10592-0069175-0

Garrison, N.L., Johnson, P.D. \& Whelan, N.V. (2020). Conservation genomics reveals low genetic diversity and multiple parentage in the threatened freshwater mussel, Margaritifera hembeli. bioRxiv, 2020.03.31.018689. https://doi.org/10.1101/2020.03.31.018689

Gerdol, M., Moreira, R., Cruz, F., Gómez-Garrido, J., Vlasova, A., Rosani, U., et al. (2020). Massive gene presenceabsence variation shapes an open pan-genome in the Mediterranean mussel. Genome Biology, 21(1), 275. https://doi.org/10.1186/s13059-020-02180-3

Grobler, P.J., Jones, J.W., Johnson, N.A., Beaty, B., Struthers, J., Neves, R.J., et al. (2006). Patterns of Genetic Differentiation and Conservation of the Slabside Pearly Mussel, Lexingtonia dolabelloides (Lea, 1840) in the Tennessee River Drainage. Journal of Molluscan Studies, 72(1), 65-75. https://doi.org/10.1093/mollus/eyi055

Hüppop, K. (2012). Adaptation to Low Food. Encyclopedia of caves (2nd Ed.). White W.B. \& Culver D.C: Amsterdam, The Netherlands, pp. 1-9.

Jalžić, B. (1998). The stygobiont bivalve Congeria kusceri Bole, 1962. (Bivalvia, Dreissenidae) in Croatia. Natura Croatica, 7(4), 341-347.

Jalžić, B. (2001). The first finding of live stygobiont bivalve Congeria in Lika region, Croatia. Natura Croatica, 10(3), 231-220.

Jones, J.W., Hallerman, E.M. \& Neves, R.J. (2006). Genetic Management Guidelines for Captive Propagation of Freshwater Mussels (Unionoiidea). Journal of Shellfish Research, 25(2), 527-535. https://doi.org/10.2983/0730-8000(2006)25[527:GMGFCP]2.0.CO;2

Jovanović Glavaš, O., Jalžić, B. \& Bilandžija, H. (2016). Population density, habitat dynamic and aerial survival of relict cave bivalves from genus Congeria in the Dinaric karst. International Journal of Speleology, 46(1). https://doi.org/<p>https://doi.org/10.5038/1827-806X.46.1.2020</p >

Kiel, C.M., Ghosh, A., Willis, K., Maltzman, F., Stratton, M., Gilbert, T.P., et al. (2020). Memmorandum of Understanding among the Parties of the Earth Biogenome Project.

Lopes-Lima, M., Teixeira, A., Froufe, E., Lopes, A., Varandas, S. \& Sousa, R. (2014). Biology and conservation of freshwater bivalves: past, present and future perspectives. Hydrobiologia, 735(1), 1-13. https://doi.org/10.1007/s10750-014-1902-9

Mammola, S., Cardoso, P., Culver, D.C., Deharveng, L., Ferreira, R.L., Fišer, C., et al. (2019a). Scientists' Warning on the Conservation of Subterranean Ecosystems. BioScience, 69(8), 641-650. https://doi.org/10.1093/biosci/biz064

Mammola, S., Piano, E., Cardoso, P., Vernon, P., Domínguez-Villar, D., Culver, D.C., et al. (2019b). Climate change going deep: The effects of global climatic alterations on cave ecosystems. The Anthropocene Review, 6(1-2), 98-116. https://doi.org/10.1177/2053019619851594

McCartney, M.A., Auch, B., Kono, T., Mallez, S., Zhang, Y., Obille, A., et al. (2019). The Genome of the Zebra Mussel, Dreissena polymorpha: A Resource for Invasive Species Research. bioRxiv, 696732. https://doi.org/10.1101/696732

McGaugh, S.E., Gross, J.B., Aken, B., Blin, M., Borowsky, R., Chalopin, D., et al. (2014). The cavefish genome reveals candidate genes for eye loss. Nature Communications, 5(1), 5307. https://doi.org/10.1038/ncomms6307

Moritz, C. (1994). Defining 'Evolutionarily Significant Units' for conservation. Trends in Ecology \& Evolution, 9(10), 373-375. https://doi.org/10.1016/0169-5347(94)90057-4 
Morton, B. \& Puljas, S. (2013). Life-history strategy, with ctenidial and pallial larval brooding, of the troglodytic 'living fossil' Congeria kusceri (Bivalvia: Dreissenidae) from the subterranean Dinaric Alpine karst of Croatia. Biological Journal of the Linnean Society, 108(2), 294-314. https://doi.org/10.1111/j.10958312.2012.02020.x

Morton, B., Velkovrh, F. \& Sket, B. (1998). Biology and anatomy of the 'living fossil' Congeria kusceri (Bivalvia: Dreissenidae) from subterranean rivers and caves in the Dinaric karst of the former Yugoslavia. Journal of Zoology, 245(2), 147-174.

Moss, D.K., Ivany, L.C., Judd, E.J., Cummings, P.W., Bearden, C.E., Kim, W.-J., et al. (2016). Lifespan, growth rate, and body size across latitude in marine Bivalvia, with implications for Phanerozoic evolution. Proceedings of the Royal Society B: Biological Sciences. https://doi.org/10.1098/rspb.2016.1364

OIKON \& Elektroprojekt. (2016). Studija o utjecaju na okoliš HES Kosinj.

Puljas, S., Peharda, M., Morton, B., Giljanović, N.Š. \& Jurić, I. (2014). Growth and Longevity of the „Living fossil” Congeria kusceri (Bivalvia: Dreissenidae) from the Subterranean Dinaric Karst of Croatia. Malacologia, 57(2), 353-364. https://doi.org/10.4002/040.057.0208

Rigonni, H., Bilandžija, H. \& Engel, A.S. (2021). Food web analysis for a stygobitic community in Croatian karst using stable isotopes. in print.

Skidmore, R., Leach, C., Hoffman, J., Amos, W. \& Aldridge, D. (2010). Conservation genetics of the endangered depressed river mussel, Pseudanodonta complanata, using amplified fragment length polymorphism (AFLP) markers. Aquatic Conservation: Marine and Freshwater Ecosystems, 20(5), 560-567. https://doi.org/10.1002/aqc.1131

Stepien, C.A., Morton, B., Dabrowska, K.A., Guarnera, R.A., Radja, T. \& Radja, B. (2001). Genetic diversity and evolutionary relationships of the troglodytic 'living fossil'Congeria kusceri (Bivalvia: Dreissenidae). Molecular Ecology, 10(8), 1873-1879. https://doi.org/10.1046/j.0962-1083.2001.01329.x

Vranješ, M., Prskalo, M. \& Džeba, T. (2013). Hidrologija i hidrogeologija sliva Neretve i Trebišnjice, osvrt na izgradnju dijela he sustava-gornji horizonti. e-Zbonik: Electronic collection of papers of the Faculty of Civil Engineering, 5, 1-23.

Zhang, G., Fang, X., Guo, X., Li, L., Luo, R., Xu, F., et al. (2012). The oyster genome reveals stress adaptation and complexity of shell formation. Nature, 490(7418), 49-54. https://doi.org/10.1038/nature11413 